\title{
The Role of Midwife Therapeutic Communication With Anxiety Levels in Maternity at The Limboro Health Center in 2020
}

\author{
${ }^{1}$ Rusnawati, ${ }^{2}$ Muhammad Syafar, ${ }^{3}$ Sitti Maisuri Tadjuddin Chalid, ${ }^{4}$ Werna Nontji, ${ }^{5}$ Rosita \\ ${ }^{1}$ Doctoral Program, Medical Faculty, Hasanuddin University, Indonesia \\ ${ }^{2}$ Department of Health Promotion, Public Health Faculty, Hasanuddin University, Indonesia \\ ${ }^{3}$ Department of Obstetrics and Gynecology, Medical Faculty, Hasanuddin University, Indonesia \\ ${ }^{4}$ Department of Nursing, Nursing Faculty, Hasanuddin University, Indonesia \\ ${ }^{5}$ Department of Midwifery, Nursing and Midwifery Faculty, Megarezky University, Indonesia \\ ${ }^{1,2,3,4}$ Perintis Kemerdekaan St, KM.10, Makassar, South Sulawesi, 90245 \\ ${ }^{5}$ Antang Raya St, No.43, Makassar, South Sulawesi, 90234 \\ E-mail: kamalrusnawati@gmail.com
}

\begin{abstract}
Anxiety has an impact on the duration of the first and second stages of labor. Generally, anxiety during labor is caused by fear of giving birth. To reduce the level of anxiety, it is necessary to communicate with therapeutic midwives in creating good relationships with maternity mothers so that there is an exchange of information, feelings, and thoughts. This research aims to find the relationship between the therapeutic communication of midwives with the level of anxiety in maternity mothers. The research method uses a cross-sectional study with a sample of 30 maternity mothers who were selected based on the purposive sampling technique. The results of the study from 30 respondents, the percentage of mothers who received therapeutic communication was not good with mild anxiety levels as many as 4 respondents (66.7\%), while at moderate and severe levels of anxiety each 1 respondent (16.7\%). Bivariate analysis with chi-square test showed p-value $=0.014$ with a significance level of $\alpha=0.05$, where $p<\alpha(0.05)$ so it can be concluded that there is a relationship between the midwife's therapeutic communication with the level of maternal anxiety. It is recommended to manage the psychological condition of the mother during pregnancy monitoring so that the anxiety and worries of the mother before delivery can be resolved properly.
\end{abstract}

Keywords: Therapeutic communication, Anxiety level, Labor 


\section{INTRODUCTION}

Anxiety is a normal condition that occurs in various circumstances, such as growth, changes, and new experiences (Mandagi, 2013). Anxiety is a feeling of fear that has no clear cause and is not supported by the existing situation (Usman, 2016). Anxiety cannot be avoided from everyday life (Saseno, 2013). Anxiety can be felt by everyone if they experience pressure and deep feelings that cause psychiatric problems and can develop in the long term (Shodiqoh, 2014).

Anxiety disorders are one of the most common psychiatric disorders. According to a report by The National Comorbidity Study, one in four people meets the diagnostic criteria for at least one anxiety disorder. Anxiety disorders are also more common in women (30.5\%) than men (19.2\%) (Sadock, 2015).

In Indonesia, there are 107,000 (28.7\%) maternity mothers who experience anxiety in facing childbirth (Mandagi, 2013). In a study conducted by Astria (2009) showed more anxiety experienced in primiparous mothers (first delivery) as much as $66.2 \%$, compared to anxiety in multiparous mothers as much as $42.2 \%$. (Nurul 2017).

Anxiety during the first stage of labor is caused by fear of childbirth. Fear of increased pain, fear of damage or body deformities such as episiotomy, rupture, stitches, or cesarean section, and the mother is afraid of hurting her baby. The mother's knowledge factor in dealing with childbirth is a very important factor influencing whether or not the birth process runs smoothly.

Therapeutic communication is important to every patient before any medical action is taken, including patients who are about to give birth. Therapeutic communication is a way to build a therapeutic relationship that is needed for the exchange of information, feelings, and thoughts to form therapeutic intimacy. Good therapeutic communication is expected to minimize the level of anxiety in the face of childbirth.

Overcoming or reducing patient anxiety is one of the midwife's tasks. One way is by communication. Therapeutic communication is expected to reduce the anxiety of the patient's family because the family feels that their interaction with the midwife is an opportunity to share knowledge, feelings, and information so that they can overcome anxiety.

\section{METHODS}

This type of research is analytic observational, where the research aims to see the relationship between therapeutic communication and anxiety levels in the first stage of labor. The approach used is cross-sectional, a type of research in which the independent and dependent variables are measured once simultaneously and at the same time.

This research was conducted at the Limboro Health Center in 2020 starting from September to November 2020. 
The population in this study were all physiological inpartu mothers at the Limboro Health Center during the study as many as 53 people.

The size of the sample taken is 30 mothers inpartu at the Limboro Health Center by using a non-probability sampling technique, namely purposive sampling. Or in other words, the purposive sampling technique is a way of taking research subjects who will become respondents in research based on certain criteria, namely inclusion and exclusion criteria.

The source of data collection used in this study is primary data. Primary data was obtained from a structured questionnaire sheet and in the form of a scale and contained questions related to the variables studied. After all the data obtained have been accurate, the analysis process is carried out in two ways, namely: Univariate and Bivariate analysis using the chi-square test.

\section{RESULTS AND DISCUSSION}

Univariate analysis to describe the characteristics of respondents is shown in table 1.

Table 1. Distribution of Characteristics of Respondents by Age at the Limboro Health Center in 2020

\begin{tabular}{ccc}
\hline Age & Frequency & Percentage $(\%)$ \\
\hline $20-25$ Years & 20 & 66.7 \\
$26-30$ Years & 10 & 33.3 \\
Total & 30 & 100.0 \\
\hline
\end{tabular}

Based on Table 1. It shows that of the 30 respondents, the highest number is at the age of 2025 years, as many as 20 respondents $(66.7 \%)$. While the least number of respondents, namely the age of 26-30 years, was 10 respondents (33.3\%).

Table 2. Distribution of respondent characteristics based on education at the Limboro Health Center in 2020

\begin{tabular}{ccc}
\hline Education & Frequency & Percentage $(\boldsymbol{\%})$ \\
\hline SD & 6 & 20.0 \\
Junior high school & 7 & 23.3 \\
Senior high school & 13 & 43.3 \\
D3 & 2 & 6.7 \\
S1 & 2 & 6.7 \\
Total & 30 & 100.0 \\
\hline
\end{tabular}

Based on Table 2. that of the 30 respondents, the highest number was at the high school education level as many as 13 respondents (43.3\%), while the least education level was at the D3 and S1 education levels with a percentage of $6.7 \%$ each ( 2 respondents).

Table 3. Distribution of Respondents Characteristics by Occupation at the Limboro Health Center in 2020

\begin{tabular}{ccc}
\hline Education & Frequency & Percentage $(\%)$ \\
\hline IRT & 19 & 63.3 \\
Teacher & 1 & 3.3 \\
\hline
\end{tabular}


E-ISSN: 2808-5361 http://e-journal.fkmumj.ac.id/
Proceeding The First Muhammadiyah InternasionalPublic Health and Medicine Conference

\begin{tabular}{ccc}
\hline Honorary & 3 & 10.0 \\
Farmer & 4 & 13.3 \\
Civil Servant & 3 & 10.0 \\
Total & 30 & 100.0 \\
\hline
\end{tabular}

Based on Table 3. shows that of the 30 total respondents, the highest number is at the IRT employment level as many as 19 respondents $(63.3 \%)$, while the least employment level at the teacher level is 1 respondent with a percentage (3.3\%).

Table 4. Distribution of Midwife Therapeutic Communication Frequency in the Delivery Room at the Limboro Health Center in 2020

\begin{tabular}{ccc}
\hline Therapeutic Communication & Frequency & Percentage $(\%)$ \\
\hline Well & 24 & 80.0 \\
Not enough & 6 & 20.0 \\
Total & 30 & 100.0 \\
\hline
\end{tabular}

Based on Table 4. shows that of the 30 respondents of midwife therapeutic communication in the delivery room of the Limboro Health Center in 2020, in the good category there were 24 people $(80.0 \%)$ and the less category was $6(20.0 \%)$.

Table 5. Frequency Distribution of Maternal Anxiety Levels at the Limboro Health Center in 2020

\begin{tabular}{ccc}
\hline Worry & Frequency & Percentage (\%) \\
\hline Light & 28 & 93.3 \\
Currently & 1 & 3.3 \\
Heavy & 1 & 3.3 \\
Total & 30 & 100.0 \\
\hline
\end{tabular}

Table 5. shows that of the 30 respondents the level of anxiety in maternity at the Limboro Health Center in 2020 in the mild anxiety category as many as 28 respondents (93.3\%), the moderate anxiety category amounted to 1 respondent (3.3\%), and the severe anxiety category was 1 respondent (3.3). \%).

Table 6. The Relationship between Therapeutic Communication and Maternal Anxiety Levels at the Limboro Health Center

\begin{tabular}{|c|c|c|c|c|c|c|}
\hline \multirow{2}{*}{ Therapeutic Communication } & \multicolumn{3}{|c|}{ Anxiety Level } & \multirow{2}{*}{ Total } & \multirow{2}{*}{$p$} & \multirow{2}{*}{$\alpha$} \\
\hline & Rgn & SDG & Brt & & & \\
\hline Well & 24 & 0 & 0 & 24 & & \\
\hline Not enough & 4 & 1 & 1 & 6 & 0.014 & 0.05 \\
\hline Total & 28 & 1 & 1 & 30 & & \\
\hline
\end{tabular}

Table 6 . shows that $100 \%$ of mothers who were given midwife therapeutic communication with good category (24 respondents) had mild anxiety levels. The percentage of mothers who received less good therapeutic communication with mild anxiety levels were 4 respondents $(66.7 \%)$. Meanwhile, at the level of moderate and severe anxiety, there was 1 respondent with poor therapeutic communication (16.7\%) and at the level of mild anxiety, there were 4 respondents (66.7). 
Based on the results of statistical tests using a chi-square with a $2 \times 3$ table on the Pearson chisquare, the $\mathrm{p}$-value $=0.014$. The $\mathrm{p}$-value $<0.05$ so it can be concluded that there is a relationship between the midwife's therapeutic communication with the anxiety level of the mother giving birth at the Limboro Health Center.

Mothers who give birth must have excessive emotions that can cause anxiety. Anxiety that arises can be caused by two factors, namely between pleasure and pain that is being felt. One form of anxiety is in the form of primary anxiety that arises because they know they have given birth (birth trauma). Which is the basis for the emergence of neurotic anxiety. One form is lah-free-floating anxiety, which is a state of anxiety in which the individual is always waiting for something bad that might happen. As a result, he will always be in a state of anxiety for fear of facing bad consequences in uncertain situations (Varney, 2015).

Maryunani (2011) explains that the anxiety experienced by mothers at the beginning of labor is related to various factors related to the labor process. Where the ways to reduce anxiety include: providing information to reduce anxiety clear fears, making cooperative relationships with companions, being good listeners, showing a sympathetic attitude, helping, and being communicative to mothers who will give birth.

Childbirth is a stressful event that causes increased pain, fear, and anxiety. During pregnancy, mothers experience physical and psychological changes that occur due to hormonal changes. These changes will make it easier for the fetus to grow and develop until the time it is born. The primiparas experienced a long labor process than the multiparas so that the primiparas experienced longer labor pains. This causes the primipara to feel more tired, the perception of pain increases, and the fear is more severe which can increase the intensity of the pain (Restyla, 2013).

The research assumption is that the level of anxiety in maternity mothers is different. This anxiety can be influenced by the mother's psychology, family support in dealing with childbirth, and the midwife's communication. The way to overcome anxiety in mothers is to accompany and provide correct information about the mechanism of labor, how to adapt when dealing with childbirth and provide a sympathetic attitude.

\section{CONCLUSIONS AND SUGGESTIONS}

This study concludes that there is a relationship between the role of the midwife's therapeutic communication with the level of anxiety in childbirth at the Limboro Health Center.

It is recommended to related parties such as health workers to pay attention to the psychological condition of the mother when doing ANC so that there is no anxiety and fear experienced by mothers who will prepare for childbirth and during childbirth so that the worries and anxieties that occur in mothers can be resolved properly. For respondents To be able to increase 
knowledge about the importance of regular checkups and consultations with doctors to prepare for safe delivery.

\section{REFERENCES}

Augustine, IM. 2012. The Relationship between Therapeutic Communication and Anxiety Levels of Inpatients at BP RSUD Kebumen. Scientific Journal of Health, Vol.5.

Ai Yeyeh, R. 2011. Midwifery Care 1. Jakarta: CV. Media Info Trans.

Anggrita, S., Mardiatul, UI, \& Ramalida, D. (2015). Midwifery Care in Pregnancy. Bogor: In Media.

Makassar City Health Office. 2018. Profile of the Makassar City Health Office.

Enggar, DKK. 2019. Textbook of Pregnancy. Jakarta : In Media.

Hawari, D 2013. Stress Management Anxiety and Stress. Edition 2, Jakarta : FKUI.

Ibrahim, AS 2012. Panic Neurosis and Anxiety Disorders. Tangerang: Explore Nusa.

Janiwarty B, Pieter HZ. 2013. Psychological Education for Midwives: A Theory and Its Application. Rapha Publishing. Yogyakarta

Luthfia \& Azizah. 2015. The Relationship of Midwife Therapeutic Communication with Maternal Anxiety in Hospital Class B DR.R. Sosodoro Djatikoesoemo Bojonegoro. D3 Midwifery.

Rahmita, Nurul. 2017. Anxiety Levels in Third Trimester Primigravida Pregnant Women at the Tamalanrea District Health Center. Makassar: Faculty of Medicine UNHAS.

Rahmy, C 2013. The Relationship of Anxiety Levels with the Smooth Process of Primigravida Delivery at the Mother and Child Hospital Banda Aceh. D3 Midwifery Banda Aceh.

Rita, Yusnita. 2012. The Relationship between Midwife Therapeutic Communication and Maternal Anxiety in the Midwifery and Maternity Room at the Pidie Regional General Hospital. D3 Midwifery STIKes U'Budiyah Banda Aceh.

Sulisdian M, et al. 2019. Textbook of Childbirth and Newborn Care. Surakarta: CV Oase Group.

Syamsuni, HR. 2019. Statistics \& Research Methodology with Android Learning Implementation. Bojonegoro: KBM Indonesia.

UTF. 2018. Indonesian Health Profile Data and Information : Jakarta Indonesia.

Walyani, ES 2015. Midwifery Care in Pregnancy. Yogyakarta : New Library Yes. 